\title{
STRATEGI ADAPTASI MASYARAKAT TERDAMPAK PEMBANGUNAN WADUK JATIGEDE DI DUSUN GIPONDOH DESA PAWENANG KECAMATAN JATINUNGgaL KabUpatEN SUMEDANG
}

\author{
THE ADAPTATION STRATEGY OF SOCIETY \\ IN THE IMPACT OF DAM CONTRUCTION OF JATIGEDE IN CIPONDOH, \\ PAWENANG VILLAGE, JATINUNGGAL SUB-DISTRICT, SUMEDANG REGENCY
}

\author{
Risa Nopianti, Triesya Melinda, Junardi Harahap \\ Program Studi Antropologi Pasca Sarjana Fisip Unpad \\ Jln. Bukit Dago Utara No.25, Bandung 40135 \\ e-mail : risanopianti@gmail.com, melindatriesya @gmail.com, junardiharahap@gmail.com
}

Naskah Diterima:16 Januari $2018 \quad$ Naskah Direvisi:13 Februari $2018 \quad$ Naskah Disetujui:3 Maret 2018

\begin{abstract}
Abstrak
Pasca penggenangan Waduk Jatigede pada tahun 2015, sejumlah permasalahan muncul pada masyarakat terdampak, seperti kesulitan dalam beradaptasi di lingkungan baru, antisipasi pengetahuan yang minim, perubahan kondisi, dan mata pencaharian yang terbatas. Keterbatasan juga terjadi pada kondisi sanitasi di lingkungan tempat tinggal mereka. Adaptasi dilakukan untuk menyiasati keadaan alam dan lingkungan yang berimbas pada pemenuhan sarana sanitasi. Maka, penelitian ini dilakukan untuk melihat bagaimana kondisi lingkungan dan sanitasi masyarakat Dusun Cipondoh Desa Pawenang Kecamatan Jatinunggal sebagai akibat pemukiman kembali pembangunan Waduk Jatigede, dengan menggunakan metode etnografi dan pendekatan kualitatif. Hasil penelitian ini menemukan bahwa pengelolaan lingkungan dan sanitasi warga Dusun Cipondoh merupakan bagian dari proses adaptasi mereka di lingkungan barunya. Proses adaptasi ini merupakan sebuah tindakan yang diawali oleh adanya pengetahuan mengenai keterbatasan yang dihadapi, kemudian disusunlah strategi untuk memunculkan tindakan yang nyata dalam menyikapi keterbatasan tersebut yang dioperasionalkan dengan pengelolaan lingkungan dan sanitasi warga terdampak.
\end{abstract}

Kata kunci: strategi, adaptasi, sanitasi, dan lingkungan.

\begin{abstract}
After the flooding of Jatigede dam in 2015, a number of problems arise in impacted communities in their daily activities, such as difficulties in adapting to a new environments, minimizing knowledge anticipation, changing conditions, and limited livelihoods. This limitation also occurs in sanitary conditions in their neighborhoods. Adaptation is done to deal with the natural and environmental conditions that impact on the fulfillment of sanitation facilities. So, this research is done to see how the environmental condition and sanitation of Cipondoh Village Pawenang Village Jatinunggal Subdistrict as a result of resettlement of Jatigede dam development by using ethnography approach to capture the point of view of indigenous people, their relationship with life, and to realize their vision and world. The results of this study is that environmental management and sanitation of Dusun Cipondoh residents is part of their adaptation process in their new environment. This adaptation process is an action initiated by the knowledge of the constraints faced, and then devised a strategy to bring tangible action in addressing the limitations that are operated with environmental management and sanitation of affected people.
\end{abstract}

Keywords: strategy, adpatation, sanitation, and environment. 


\section{A. PENDAHULUAN}

Waduk Jatigede yang terletak di Kabupaten Sumedang merupakan waduk buatan terbesar kedua di Indonesia setelah Waduk Jatiluhur yang telah ada sebelumnya. Waduk ini mampu menampung 6,7 juta $\mathrm{m} 3$ (Wiryawan, 2017) air yang berfungsi untuk irigasi, pengendali banjir, pembangkit listrik, dan penyedia air baku. Air Waduk Jatigede sekiranya dapat difungsikan untuk mengaliri irigasi pesawahan seluas 90.000 ha lahan pertanian yang berada di Sumedang, Majalengka, dan Cirebon, dan potensi listrik yang dihasilkan oleh PLTA Jatigede sebesar 110 megawatt (MW) yang sampai tahun ini masih dalam tahap rekonstruksi ${ }^{1}$.

Tahap persiapan pembangunan Waduk Jatigede yang sekiranya direncanakan pada tahun 1963, yaitu pada masa kepemimpinan Presiden RI pertama Ir. Soekarno ternyata terkendala berbagai masalah hingga pembangunannya tersendat. Pada tahun 1986, SMEC sebuah konsultan dari Australia kemudian melanjutkan pembuatan detail design. Selanjutnya pada tahun 2004 pekerjaan ini direview kembali oleh PT. Indra Karya JO dan PT. Wiratman, (konsultan yang telah memegang sertifikat dari Kementerian Pekerjaan Umum). (Nurlela, 2012: 4). Akhirnya setelah lebih dari 50-an tahun kemudian dapat direalisasikan meski masih menyisakan kontroversi dan permasalahan lain yang belum terselesaikan.

Kondisi pembangunan Waduk Jatigede telah banyak menyedot perhatian banyak orang, hingga isu tersebut menjadi isu nasional yang dalam beberapa tahun terakhir ini ramai dipebincangkan baik dalam tataran praktis maupun kajian-kajian keilmuan. Pada tataran praktis isu-isu pembangunan Jatigede dikaitkan dengan kondisi sosial ekonomi masyarakat terdampak yang pada saat itu harus menanggung kerugian secara material

\footnotetext{
${ }^{1}$ http://properti.kompas.com/read/2017/04/07/2 20000521/waduk.jatigede.beroperasi.penuh diakses 6 November 2017
}

maupun immaterial terhadap pembangunan Waduk Jatigede. Kerugian material mencakup pemberian ganti rugi lahan dan bangunan yang menurut sebagian masyarakat tidak sepadan dengan apa yang dahulu mereka miliki. Adapun kerugian immaterial berkaitan dengan hilangnya warisan budaya masyarakat terdampak seperti situs-situs bersejarah yang akhirnya harus tergelam bersama kenangan mereka terhadap warisan leluhurnya. Setiawan (2016) mengatakan bahwa kesulitan terbesar pembangunan Waduk Jatigede adalah relokasi warga yang memiliki adat dan kebiasaan yang dijalankan secara turun temurun. Adat dan kebiasaan mereka sangat terkait dengan kondisi alam yang sekaligus menjadi lokasi tinggal para leluhur mereka.

Pada tataran keilmuan berbagai kontroversi juga muncul terkait adanya studi-studi terhadap pembangunan Waduk Jatigede terutama pada bidang-bidang ilmu bumi, teknik, dan lingkungan yang banyak mengkaji dampak yang diakibatkan oleh pembangunan Waduk Jatigede terhadap kondisi ekologis wilayah genangan. Permasalahan lingkungan yang mencuat adalah mengenai hilangnya ekosistem alam serta lahan subur petanian seluas 4.891,13 ha. Di sisi lain masalah geologi juga muncul terkait dengan resistensi bendungan terhadap kondisi tanah yang ada di daerah Jatigede.

Seiring dengan berjalannya waktu, di bawah kepemimpinan Presiden Jokowi, akhirnya pembangunan Waduk Jatigede terealisasi juga setelah melalui masa konstruksi selama 6 tahun. Tepat pada tanggal 31 Agustus 2015 Waduk Jatigede resmi digenangi oleh aliran Sungai Cimanuk-Cisanggarung yang dibendung. Proses penggenangan ini dilakukan selama 219 hari oleh Kementerian Pekerjaam Umum dan Perumahan Rakyat.

Waduk Jatigede berada pada kilometer 19 arah timur Kabupaten Sumedang serta memiliki luas 3.035,34 ha. Ada 23 desa yang harus tergenang oleh Waduk Jatigede yang berasal dari empat 
kecamatan di Kabupaten Sumedang yaitu Wado, Darmaraja, Jatigede, dan Jatinunggal. Dari total 23, hanya 6 desa yang benar-benar harus tenggelam, sisanya tenggelam sebagian. Keenam desa tersebut adalah Desa Sukakarta (Kecamatan Jatigede), Desa Padajaya (Kecamatan Wado), Desa Leuwihideung, Cibogo, Cipaku, dan Cibungur (Kecamatan Darmaraja).

Pembangunan Waduk Jatigede merupakan sebuah musibah komunal yang dirasakan oleh masyarakat Jatigede, khususnya bagi mereka warga terdampak. Buktinya setelah dua tahun berselang pasca penggenangan, masih menyisakan permasalahan-permasalahan yang dihadapi masyarakat terdampak khususnya dalam menjalani aktivitas mereka sehari-hari. Perubahan sosial budaya, ekonomi dan lingkungan yang terjadi pada masyarakat terdampak, secara otomatis menuntut perlunya sebuah strategi adaptasi untuk menyikapi kesulitan-kesulitan yang dihadapi. Strategi adaptasi secara sosial juga diperlukan untuk mengantisipasi pengetahuan masyarakat dalam menghadapi situasi-situasi kritis yang terjadi pasca pemindahan lokasi dengan fasilitas pendukung yang sangat minim, yang tentunya dapat meningkatkan stress sehingga berakibat pada menurunnya tingkat kesehatan pada masyarakat.

Masyarakat terdampak pembangunan Waduk Jatigede terutama yang berasal dari enam desa yang tenggelam adalah yang paling merasakan dampak secara langsung dan berat dari pembangunan Waduk Jatigede. Selain kehilangan mata pencaharian utama $^{2}$ sebagai petani, mereka juga belum dapat mengembangkan mata pencaharian lain di tempat barunya hingga kemudian banyak dari mereka yang menganggur tanpa pekerjaan yang jelas. Belum lagi lingkungan alam tempat mereka tinggal saat ini kondisinya sangat berbeda dengan

\footnotetext{
${ }^{2}$ Menurut hasil penelitian Wiryawan (2017) sebanayak $88 \%$ warga terdampak kehilangan pekerjaannya.
}

tempat mereka dahulu yang sangat subur dan hijau, kondisinya saat ini gersang dan panas. Perubahan ini terjadi setelah mereka direlokasi ke tempat baru.

Seperti halnya yang terjadi pada masyarakat relokasi di Dusun Cipondoh, Desa Pawenang Kecamatan Jatigede, mereka adalah masyarakat yang direlokasi secara bedol desa yang berasal dari Desa Padajaya Kecamatan Wado yang tenggelam bersamaan dengan pembangunan Waduk Jatigede. Sebagian besar dari mereka kembali berkumpul di Dusun Cipondoh, namun sebagian lainnya memilih untuk tinggal di tempat lain.

Permasalahan yang mereka hadapi di tempat tinggal barunya tidaklah ringan, selain berhadapan dengan kondisi alam yang tidak sama dengan sebelumnya, mereka juga harus mampu bertahan dengan mata pencaharian yang terbatas demi kelangsungan hidupnya. Kondisi serba terbatas ini juga terjadi pada kondisi sanitasi di lingkungan tempat tinggal mereka. Adaptasi dilakukan untuk menyiasati keadaan alam dan lingkungan yang berimbas pada pemenuhan kebutuhan hidup dasar.

Penelitian ini dilakukan untuk melihat strategi adaptasi khususnya yang berkenaan dengan kondisi lingkungan dan sanitasi yang dilakukan oleh masyarakat Dusun Cipondoh Desa Pawenang Kecamatan Jatigede sebagai akibat dari adanya program pemukiman kembali lingkungan tempat tinggal warga terdampak pembangunan Waduk Jatigede. Titik fokus penelitian ini adalah untuk melihat bagaimana kondisi sanitasi dan lingkungan yang mereka kembangkan dapat membantu mereka memenuhi kebutuhan-kebutuhan hidup sebagai salah satu upaya beradaptasi dengan lingkungan barunya.

Penelitian-penelitian mengenai kondisi sanitasi yang berhubungan dengan penyakit-penyakit endemik tertentu telah banyak dilakukan oleh beberapa orang peneliti, seperti Kasnodihardjo, dkk. (2009), Yuliati, dkk. (2010), Amaliah 
(2010), Sajida, dkk. (2012), dan Puspitawati (2013), yang membahas mengenai hubungan antara kondisi sanitasi dan higienitas tempat tinggal atau lingkungan dengan penyakit-penyakit seperti flariasis, demam berdarah, penyakit kulit, cacingan, dan gizi buruk. Artikel tersebut juga memaparkan mengenai hubungan sanitasi dengan gaya hidup dan perilaku hidup bersih.

Penelitian lain yang mengkhususkan pada penelitian pembangunan Waduk Jatigede serta dampak sosial, budaya dan lingkungan yang ditimbulkan pernah dibahas juga oleh beberapa orang peneliti di antaranya Nureni (2011), Nurlela (2012), Setianto (2014), Mulyani (2016), Setiawan (2016), Wiryawan (2017). Kumpulan penelitian tersebut berkisar pada dampak kebijakan, konflik sosial, kondisi budaya, serta dampak permasalahan ekonomi dan ketenagakerjaan yang ditimbulkan dalam pembangunan Waduk Jatigede.

Dari keseluruhan hasil-hasil penelitian yang telah dipublikasikan di atas, hampir tidak ada yang membahas mengenai kondisi sanitasi dan lingkungan masyarakat $\mathrm{di}$ wilayah resettlement ${ }^{3}$, khususnya di Jatigede. Oleh sebab itu penelitian ini dilakukan untuk melihat bagaimana kondisi sanitasi dan lingkungan masyarakat yang terkena dampak pemukiman kembali, supaya diperoleh hasil yang komprehensif mengenai kajiankajian terkait pembangunan Waduk Jatigede secara keseluruhan.

Untuk menjelaskan fenomena tersebut, berikut ini dipaparkan sejumlah konsep yang sekiranya berhubungan dengan permasalahan penelitian yang akan dibahas.

\footnotetext{
${ }^{3}$ Resettlement adalah Proses pemindahan penduduk untuk bertempat tinggal di tempat lain, karena tempat sebelumnya sudah tidak dapat lagi atau tidak diperbolehkan lagi untuk ditempati atau digunakan.
}

\section{Resettlement (Pemukiman Kembali)}

Menurut Bartolome, et.al (2000: 5), saat ini program pemukiman kembali lebih banyak difokuskan pada proses relokasi fisik saja, bukan pada perkembangan ekonomi dan sosial masyarakat terdampak. Hal ini tentunya meningkatkan risiko pemiskinan bagi para pemukimnya.

Risiko ekonomi utama yang dihadapi masyarakat terdampak berasal dari hilangnya mata pencaharian dan sumber pendapatan seperti lahan subur, hutan, penggembalaan ladang, tanah dan air permukaan, perikanan, dan lain-lain. Mereka juga mengalami perubahan dan pengurangan akses dan kontrol terhadap sumber daya produktif.

Menurunnya kekuatan ekonomi masyarakat terdampak dapat menyebabkan ancaman terhadap keamanan pangan rumah tangga, yang menyebabkan kekurangan gizi. Timbulnya penyakitpenyakit yang terkait dengan kualitas air yang memburuk, juga dapat menyebabkan angka morbiditas dan mortalitas meningkat. (Bartolome, et.al. 2000: 5).

\section{Kesehatan Lingkungan Pemukiman}

Perumahan memiliki arti beberapa rumah tempat tinggal. Perumahan juga merupakan kebutuhan primer manusia, yang meliputi sandang, pangan dan papan. Perumahan menjadi kebutuhan dasar untuk memenuhi kebutuhan papan. Dalam ilmu kesehatan masyarakat, perumahan merupakan sarana dan prasarana manusia untuk bisa mendapatkan hidup sehat. ${ }^{4}$

Perumahan tidak terlepas juga dari istilah pemukiman. Secara harfiah pemukiman memiliki kata dasar dari mukim yang berarti tempat tinggal. Pemukiman ialah proses di mana manusia akan menempati tempat tinggalnya. Jadi, kata perumahan dan pemukiman tidak akan terlepas karena dapat disimpulkan sebagai bangunan untuk tempat tinggal yang akan ditempati oleh manusia untuk

\footnotetext{
${ }^{4}$ Krieger dan Higgins (2002) dalam Keman (2005: 30-32)
} 
hidup dan tinggal. Pemukiman memiliki fungsi sebagai lingkungan untuk manusia bisa beraktivitas.

Area pemukiman dapat memiliki fungsi sebagai lingkungan perumahan dengan adanya sarana dan prasarana yang memadai untuk kehidupan manusia. Pemukiman juga akan membentuk lingkungan perumahan yang lebih terstruktur dan lebih efisien untuk kehidupan manusia di mana ia tinggal. Pemukiman akan lebih terstruktur dan efisien jika ada prasarana atau penunjang yang memungkinkan untuk berjalannya suatu lingkungan perumahan. Prasarana utama dalam lingkungan pemukiman yaitu dengan adanya jalan yang memadai di area perumahan, pembuangan air limbah dan sampah yang baik di area perumahan, pembuatan saluran air/drainase air hujan yang baik, pengadaan prasarana komunikasi, jaringan listrik, ketersediaan bahan bakar, serta ketersediaan air bersih sebagai syarat untuk menjadi pemukiman yang memadai bagi masyarakat. Pengadaan prasarana ini bisa didapatkan jika suatu pemukiman dikelola dengan baik oleh suatu badan usaha tertentu (Keman, 2005: 30-32).

Setelah prasarana di dalam area pemukiman sudah memadai, akan lebih memadai jika ada alat atau sarana yang berupa fasilitas-fasilitas atau kemudahankemudahan untuk melancarkan kehidupan manusia dalam sisi sosial, ekonomi, dan budaya; seperti adanya instansi-instansi pemerintahan dalam pelayanan umum, adanya tempat pendidikan seperti sekolah, pesantren, madrasah dan lain-lain, adanya sarana kesehatan seperti bangunan Puskesmas, UPT, Posyandu, dan sarana kesehatan lainnya, adanya tempat ibadah seperti masjid, musala, gereja, pura, vihara, dan tempat ibadah sesuai agama yang dijadikan pedoman oleh manusia, adanya pusat perbelanjaan seperti pasar, mini market, warung kelontongan, supermarket, mall dan tempat jual beli untuk kebutuhan manusia, adanya sarana rekreasi dan olah raga seperti lapangan bola, lapangan voli, dan lapangan lainnya untuk sarana rekreasi dan olah raga untuk manusia, lalu juga adanya pertamanan dan pemakaman.

\section{Sanitasi Lingkungan}

Dalam mengamati kondisi kesehatan suatu masyarakat, perlu diperhatikan juga kondisi lingkungan yang ada di sekitar masyarakat bersangkutan. Karena pada dasarnya lingkungan memberikan dampak yang cukup besar terhadap kondisi kesehatan masyarakat. Selain lingkungan, perilaku masyarakat juga ikut menentukan. Menurut Kasnodihardjo (2013: 415-416) "kesehatan lingkungan adalah suatu kondisi lingkungan yang berada pada tahap optimum, yang memiliki pengaruh baik terhadap status kesehatan masyarakat".

Sanitasi berasal dari bahasa Inggris yang berarti sanitation, secara harfiah diartikan sebagai upaya-upaya menjaga kesehatan. Dalam hubungannya dengan lingkungan terdapat istilah yang disebut sanitasi lingkungan. Sanitasi lingkungan merupakan sebuah upaya untuk menjaga, mencegah, dan memelihara status kesehatan baik pada lingkungan budaya, ekonomi, sosial, maupun lingkungan fisiknya secara baik dan normal (Notoatmodjo, 2003: 5).

Senada dengan Notoatmodjo, Slamet (2001: 67) juga mengungkapkan bahwa dalam rangka mengendalikan sanitasi lingkungan yang baik maka harus lebih ditekankan kepada faktor pengawasan, pengendalian, serta kontrol terhadap situasi lingkungan manusianya seperti: kebersihan air minum; saluran pembuangan kotoran dan limbah; makanan yang bersih dan sehat; perilaku hidup bersih; sterilisasi dari hewan pengerat; dan kondisi udara yang bersih dan bebas dari pencemaran.

Untuk mengetahui kondisi sanitasi suatu masyarakat maka harus diperhatikan kondisi sanitasi lingkungannya. Terdapat beberapa hal yang penting untuk diperhatikan, yaitu MCK (Mandi Cuci, Kakus) atau jamban, saluran pembuangan air limbah, air bersih, dan sarana 
pembuangan sampah" (Kasnodihardjo dan Elsi, 2013: 416).

\section{Perilaku, Pengetahuan, Sikap, dan Tindakan}

Kondisi sanitasi lingkungan yang sehat tidak dapat terlepas dari campur tangan manusia sebagai subjek perubahan. Oleh sebab itu diperlukan adanya perilaku dan pengetahuan yang baik dan benar mengenai pengelolaan sanitasi lingkungan sehingga diperoleh status kesehatan yang ideal.

Secara umum perilaku menurut Bloom (dalam Surahman dan Supardi, 2016: 35) "mencakup perilaku kognitif (pengetahuan), afektif (emosi), dan psikomotor (gerakan, tindakan)".

Perilaku terhadap lingkungan

kesehatan (environmental health

behavior), adalah tingkah laku individu terhadap lingkungannya yang dapat mempengaruhi kesehatan manusia yang meliputi pengetahuan, sikap dan tindakan yang berhubungan dengan pembuangan air limbah, kebersihan rumah, air bersih, pembersihan vektor sarang nyamuk, dan lainnya (Surahman dan Supardi, 2016: $35)$.

Perilaku terhadap lingkungan kesehatan ini merupakan salah satu bagian saja dari keseluruhan perilaku kesehatan secara umum yang juga mencakup perilaku sakit, perilaku terhadap layanan kesehatan, dan perilaku terhadap makanan (Surahman dan Supardi, 2016).

Konsep perilaku pada dasarnya tidak dapat berdiri sendiri namum harus juga didukung dengan konsep-konsep lain untuk membuat sebuah pemahaman yang lebih komprehensif berkaitan dengan adanya upaya-upaya untuk memperoleh kondisi sanitasi lingkungan yang sehat dan ideal. Beberapa hal tersebut menurut (Surahman dan Supardi, 2016: 36) adalah:

1. Pengetahuan (knowledge), berasal dari kata "tahu" yang berarti merasakan pengalaman baru setelah menggunakan indera (perasa, pelihat, pendengar, peraba, dan pencium) terhadap sebuah objek yang ditentukan.

2. Sikap (attitude), adalah respon individu yang cenderung belum terpengaruh oleh stimulus dari luar yang berhubungan dengan pengetahuan yang dimilikinya terhadap sesuatu hal. Beberapa ahli mengatakan bahwa sikap merupakan kesiapan seseorang untuk melakukan tindakan.

3. Tindakan atau praktik (practice). pengetahuan atau sikap ini tidak selalu dapat diwujudkan melalui sebuah tindakan. Namun untuk dapat mewujudkan sebuah sikap menjadi tindakan memerlukan adanya faktor pemungkin dan pendukung utama yaitu tindakan.

\section{Adaptasi}

Konsep adaptasi ditujukan pada cara-cara penyesuaian hidup sebuah organisma atau sekelompok orang terhadap lingkungannya. Penyesuaian ini dilakukan organisma untuk menghadapi tekanan-tekanan yang terjadi pada dirinya sehingga mereka harus mampu keluar dari tekanan tersebut untuk kemudian bertahan hidup di dalam lingkungannya.

Untuk dapat bertahan hidup seorang individu atau kelompok orang harus mampu menanggulangi kesulitankesulitan yang dialaminya terutama yang berasal dari lingkungan alam dan lingkungan sosialnya. Dalam tahapan ini individu harus mampu untuk: bertahan hidup sebagai resisten terhadap musuh alaminya; memperoleh sumber daya pemenuhan kebutuhan primernya yaitu makanan, air dan udara; memperoleh air, udara dan makanan; membentuk keluarga dan keturunan; serta siap menghadapi segala perubahan yang terjadi di sekitar lingkungannya. Keseluruhan proses pertahanan diri ini disebut sebagai proses adaptasi.

Konsep adaptasi menurut Bennett (1976) berkembang dari adanya teori evolusi yang berisi tentang berkembangnya manusia secara biologis dan fisik untuk 
menyesuaikan diri dengan lingkungan alam maupun lingkungan budayanya. Konsep adaptasi menurut Bennett dalam Saharuddin (2007: 46-47) terbagi menjadi tiga yaitu ada adaptasi tingkah laku yaitu suatu tindakan atau tingkah laku dengan mempertimbangkan baik buruknya hasil yang akan didapat, lalu ada adaptasi strategi yang merupakan suatu proses atau cara di mana manusia merespon pertimbangan yang sudah dipilih dan memikirkan cara lain agar sesuai dengan kebutuhan dan tidak menimbulkan masalah dengan pihak lain, dan yang terakhir adaptasi proses yaitu perubahan-perubahan yang muncul dengan menyesuaikan strategi yang sudah dipilih dan ditunjukkan dalam waktu yang panjang.

Menurut Bennett (1976: 249-250) dalam memandang ekologi faktor-faktor yang ada di lingkungan baik eksternal maupun internal harus diidentifikasi mana hal-hal yang dianggap penting, mana yang jadi penghambat, dan mana yang bisa dikembangkan pada tingkah laku manusia. Konsep ini mengasumsikan bahwa organisasi sosial budaya merupakan hasil dari proses adaptasi manusia dalam mengantisipasi masalah yang akan datang. Bennett (1976: 250) mengemukakan bahwa:

"Basis ekologi manusia adalah kapasitas manusia untuk melakukan self objectification, belajar, dan mengantisipasi. Manusia mengkonseptualkan diri mereka sendiri agar dapat bertindak terhadap lingkungan mereka."

Berdasarkan konsep yang dikemukakan Bannet, Ahimsa Putra dalam Saharuddin (2007: 46-47) menyatakan bahwa:

"Adaptasi merujuk pada adanya sebuah proses penyesuaian terhadap suatu kondisi yang berubah. Adaptasi merupakan proses perubahan yang terjadi pada diri individu maupun individu dengan lingkungannya, yang memerlukan waktu yang cukup lama serta harus melalui serentetan tindakan yang dilakukan secara berulangulang."

Dari uraian di atas dapat diambil kesimpulan untuk menganalisa hasil penelitian ini dibutuhkan konsep adaptasi lingkungan sebagai upaya masyarakat terdampak mengembangkan strategi-strategi adaptif sebagai bentuk penyesuaian dirinya terhadap perubahan lingkungan yang tentunya juga berimbas pada perubahan sosial dan ekonomi mereka di wilayah resettlement.

\section{B. METODE PENELITIAN}

Penelitian ini ditulis menggunakan metode etnografi dengan pendekatan kualitatif $^{5}$. Adapun data diperoleh dengan melakukan proses wawancara dan observasi lapangan, yang diperkuat oleh data-data sekunder sebagai pendukung. Pemilihan informan penelitian dikhususkan pada warga terdampak resettlement pembangunan Waduk Jatigede di Dusun Cipondoh Desa Pawenang Kecamatan Sumedang. Pemilihan informan kunci sebanyak empat orang, didasarkan pada keterkaitan lingkungan pemukiman mereka di tempat baru dengan pengalaman mereka sebagai warga terdampak pembangunan Waduk Jatigede.

Hasil pengumpulan data lapangan kemudian diolah dengan tahap reduksi data, yaitu merangkum, memilah-milah, dan memfokuskan hasil yang telah diperoleh kepada hal-hal yang dianggap

\footnotetext{
${ }^{5}$ Creswell (2008) dalam Semiawan (2010: 67). Analisis data kualitatif dengan menggambarkan proses penentuan metode yang akan digunakan berdasarkan fakta, realita, masalah, peristiwa dan gejala, secara luas dan dalam untuk mendapatkan subuah pengalaman anyar yang akan dijawab oleh peneliti. Masalah penelitian bisa saja berasal dari masukan orang lain, pengalaman orang lain, atau pengalaman individu si penulis.
} 
penting, untuk selanjutnya disajikan dengan uraian deskriptif sesuai data yang ada. Langkah selanjutnya adalah verifikasi dan analisa terhadap data dan konsep yang disajikan untuk kepentingan penarikan kesimpulan dan rekomendasi hasil penelitian.

\section{Kerangka Pemikiran}

Dari uraian konsep mengenai sanitasi dan lingkungan serta adapatasi di atas, dapat ditarik sebuah analisa terhadap persoalan yang dihadapi masyarakat di Dusun Cipondoh Desa Pawenang Kecamatan Jatigede Kabupaten Sumedang. Hal ini terkait kondisi sanitasi lingkungannya untuk mendukung pola adaptasi penyesuaian dirinya terhadap lingkungan alamnya.

Persoalan resettlement yang dihadapi oleh masyarakat Cipondoh akibat pembangunan Waduk Jatigede berdampak besar terhadap perubahana sosial budaya, ekonomi, dan lingkungan masyarakat. Fokus kajian artikel ini adalah kondisi sanitasi dan lingkungan yang mereka kembangkan di pemukiman barunya merupakan bentuk dari adaptasi tingkah laku dalam menyesuaikan diri dengan keadaan lingkungannya. Proses adaptasi tingkah laku ini diperoleh melalui pengetahuan dan diwujudkan dengan tindakan-tindakan adaptif dalam menyikapi lingkungan dan sanitasinya untuk menciptakan sebuah lingkungan baru yang lebih ideal untuk ditempati dengan layak.

\section{HASIL DAN BAHASAN}

\section{Gambaran Umum Lokasi Penelitian Dusun Cipondoh Desa Pawenang Kecamatan Jatinunggal \\ a. Letak Geografis}

Desa Pawenang memiliki wilayah seluas 275,255 ha. Desa ini terdiri atas 4 dusun (Sukahening, Sukahurip, Sukajaya, dan Sukamulya) dengan 9 RW dan 31 RT. Ditambah satu dusun baru hasil relokasi warga yang terkena dampak pembangunan Waduk Jatigede yang bernama Dusun Cipondoh. Jadi saat ini total ada 5 dusun yang berada di bawah wilayah administratif Desa Pawenang Kecamatan Jatinunggal Kabupaten Sumedang.

Desa Pawenang dikelilingi oleh beberapa desa yang satu sama lain berbatasan langsung secara administratif. Di wilayah utara berbatasan

dengan Desa Mekarasih Kecamatan Jatigede; wilayah timur dibatasi oleh Desa Sirnasari dan Desa Tarikolot Kecamatan Jatinunggal; sebelah selatan berbatasan langsung dengan Desa Mulyajaya Kecamatan Wado; dan sebelah barat dibatasi secara administratif oleh Desa Wado Kecamatan Wado.

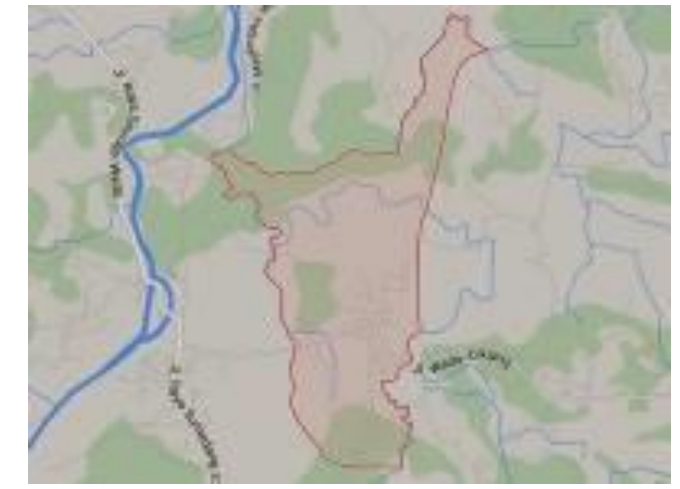

Gambar 1. Peta Desa Pawenang

Sumber: http://sumedangtandang.com/ direktori/detail/desa-pawenang

Secara geografis, Desa Pawenang berada pada wilayah paling barat Kecamatan Jatinunggal. Lokasinya yang cukup strategis sangat berpotensi untuk dikembangkan dalam pembangunan. Jarak tempuh Desa Pawenang ke kantor Kecamatan Jatinunggal sekitar $1,5 \mathrm{~km}$ dengan lama waktu tempuh sekitar 10 hingga 15 menit menggunakan kendaraan.

Jumlah penduduk Desa Pawenang sebanyak 5.542 jiwa dengan jumlah KK sekitar 1.909 yang terdiri atas 2.838 lakilaki, serta 2.704 perempuan. Adapun penambahan dari relokasi beberapa desa di genangan Waduk Jatigede sebanyak 1.118 jiwa dengan $370 \mathrm{KK}$. Komposisi kepala keluarga relokasi terbesar berada di Dusun Cipondoh. 


\section{b. Dusun Bedol Desa ${ }^{6}$ Cipondoh}

Dusun Cipondoh merupakan dusun bedol desa pindahan dari Desa Padajaya Kecamatan Wado yang saat ini telah tenggelam di dasar Waduk Jatigede. Dari 23 desa yang terkena dampak penggenangan, hanya 6 desa yang total tenggelam di dasar Waduk Jatigede, sementara desa-desa yang lain hanya tergenang sebagian. Oleh sebab itu 6 desa ini yang mendapat prioritas relokasi. Keenam desa yang tenggelam tersebut kemudian direlokasi ke beberapa daerah di sekitarnya, seperti Desa Sukakarta ke Dusun Panyariban, Desa Mekarsari, Jatigede; Desa Leuwihideung ke Desa Mekarsari, Cihegarmekar; Desa Cibogo ke Cinawing, Darmaraja; Desa Cipaku dan Cibungur ke Cisema, dan Pakualam Kecamatan Darmaraja; dan terakhir Desa Padajaya ke Dusun Cipondoh, Pawenang, Jatinunggal.

Berada di atas ketinggian 263-304 mdpl, Dusun Cipondoh memiliki penduduk sebanyak 260 KK. Penduduknya telah mendiami Dusun Cipondoh yang sebelumnya berupa tanah kas Desa Pawenang yang masih berupa perbukitan seluas 20 ha ditambah dengan tanah milik warga 40 ha. Jadi, total keseluruhan Dusun Cipondoh 60 ha. Seharusnya ada 530 KK dari Desa Padajaya yang akan dipindahkan ke tanah kas Desa Pawenang, namun karena terjadi kendala teknis ${ }^{7}$, hanya 260

${ }^{6}$ Bedol desa adalah pemindahan seluruh penghuni desa ke tempat lain. Sumber : https://www.kamusbesar.com/bedol-desa.

\footnotetext{
${ }^{7}$ Pembukaan tanah (cut and fill) menelan biaya sebesar 1,5 milyar tersebutdikerjakan selama 2 bulan, namun belum seluruhnya diselesaikan oleh pihak pelaksana yaitu PT Garuda dan PT.Trisandi, padahal untuk mempercepat prosesnya warga telah berkontribusi sebesar 2,5 juta/KK untuk pembuatan cut and fill lahan supaya bisa dibangun dan ditempati. Akibatnya sebagian warga terkatung-katung nasibnya hingga saat ini.
}

orang beruntung saja ${ }^{8}$ bisa pindah. Lebihnya sebanyak 170 keluarga menyebar ke berbagai tempat. Sebagian ada yang mengontrak, membangun rumah di tempat lain, atau menumpang di rumah kerabat.

Sebelum warga Desa Padajaya direlokasi, mereka mendapatkan uang kerohiman sebesar 29 juta per KK, namun itu hanya diperuntukkan bagi mereka yang tidak memiliki rumah, sedangkan bagi mereka yang memiliki rumah uang penggantian sebesar 122 juta.

"kompensasina anu disebat kerohiman 29 juta. Anu gaduh tunggul nyaeta anu digentos bumina eta mah 122 juta. Tah upami nu digentos bumina, kerohiman teu kenging."

Berangkat dari pengertian tunggul yang dimaksud oleh warga Cipondoh dituturkan menurut kronologis sejarah pembebasan lahan yang telah berlangsung sejak tahun 1980-an. Tunggul adalah tanah dan bangunan yang telah dibebaskan oleh pemerintah pada tahun 1984 sebagai realisasi dari Permendagri No.15 tahun 1975. Dalam Permendagri disebutkan bahwa pemerintah berkewajiban untuk memukimkan kembali masyarakat yang terkena dampak pembangunan Waduk Jatigede. Harga ganti rugi tanah saat itu Rp.6.200/14 m2, sedangkan sawah Rp. 9.200/14 m2. Proses pencairan dilakukan dengan dua tahap, uang muka dan dibagikan secara langsung di desa, sedangkan pelunasan baru sebulan sampai dua bulan kemudian di kabupaten. Kondisi

\footnotetext{
8260 KK yang beruntung menempati lahan baru di Dusun Cipondoh dilakukan dengan mekanisme kocokan. Mekanisme pengocokan kavling didasarkan siteplan yang telah ada sebelumnya untuk 530 KK Desa Padajaya, kemudian diprioritaskan terlebih dahulu bagi yang sangat memerlukannya, kemudian dikocok dan ditempatkan pada petak-petak kavling pada siteplan sebayak 260 KK terlebih dahulu.

${ }^{9}$ Wawancara dengan Bapak Carli Supriatna 17
Oktober 2017
} 
pemerintah saat itu tidak memiliki kemampuan dana yang cukup untuk membayar kompensasi, maka pembebasan lahan tersebut akhirnya jalan di tempat. Pada akhirnya warga hanya diberikan ganti rugi atas tanah dan bangunan yang nilainya tidak sesuai dengan ketentuan.

Masih banyak permasalahan yang belum terselesaikan saat itu sehingga berakibat secara umum terhadap terhambatnya pembangunan waduk.

"Jadi sebenarnya pembebasan waktu itu masih bermasalah, banyak hak masyarakat yang belum diberikan.

Entah itu tentang harga, entah itu tentang kekurangan bayar, entah tentang kekurangan luasan. Karena pada zaman itu, masyarakat nggak tahu ini teh mau diapain, mau diapakan, diukur aja ${ }^{10}$."

Kemudian peraturan baru diterbitkan untuk menindaklanjuti kondisi tersebut, yaitu dengan terbitnya Peraturan Presiden No.1 Tahun 2015 yang poin utamanya adalah konversi relokasi pemukiman, yang seharusnya masyarakat dimukimkan kembali dengan penggantian tanah seluas 28 bata $^{11}$, rumah setara tipe 36, dan biaya hidup, kemudian dikonversi dalam bentuk uang sebesar 122 juta, merata untuk setiap KK.

Di lokasi barunya yang kemudian dinamakan Dusun Cipondoh, mereka membangun rumah di lahan seluas $110 \mathrm{~m} 2$ dengan dana yang telah mereka terima dari hasil ganti rugi. Sebagian masih menempati tanah kas Desa Pawenang, dan sebagian pada tanah miliknya sendiri. Keterbatasan biaya bagi beberapa keluarga menyebabkan pembangunan rumah tinggal banyak yang tersendat (belum selesai), ada pula yang meminimalisir biaya dengan membangun rumah semi permanen. Ratarata mereka membangun rumah permanen

\footnotetext{
${ }^{10}$ Wawancara dengan Bapak Teten Informan Dusun Cipondoh, Desa Pawenang Tanggal 17 Oktober 2017

${ }^{11} 1$ bata setara dengan luas $14 \mathrm{~m} 2$. Jadi 28 bata berarti $28 \times 14=392 \mathrm{~m} 2$
}

yang layak huni dengan model-model rumah modern seperti di kota.

\section{Kondisi Lingkungan dan Sanitasi Masyarakat Terdampak di Dusun Cipondoh ${ }^{12}$}

Kondisi lingkungan dan sanitasi di Dusun Cipondoh Kecamatan Jatigede masih minim. Hasil temuan di lapangan, warga Dusun Cipondoh masih kekurangan pasokan air bersih terutama untuk minum. Air diperoleh dari sumur-sumur gali milik warga dan sumur umum. Rata-rata kedalaman sumur gali yang baik untuk menghasilkan air yang layak minum adalah 11-15 $\mathrm{m}$ untuk hasil yang maksimal. Ongkos pembuatan sumur gali yang cukup mahal membuat keberadaan sumur-sumur dengan air layak minum masih sedikit, hanya beberapa rumah tangga saja yang memilikinya, bahkan ada yang sama sekali tidak memilikinya. Untuk mengantisipasi hal tersebut dibuatlah beberapa sumur umum yang dibangun di sekitar wilayah permukiman mereka. Biaya yang dibutuhkan untuk membuat sebuah sumur umum sebesar 15 juta rupiah, yang dikumpulkan dari sumbangan warga.

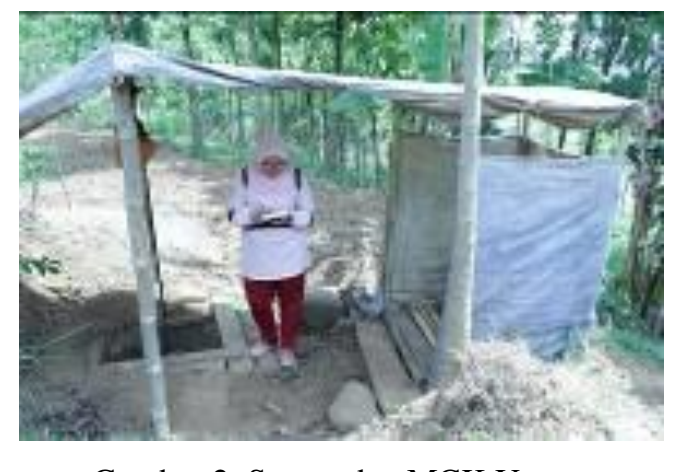

Gambar 2. Sumur dan MCK Umum Sumber: Dok. Pribadi, 2017.

Beberapa rumah tangga tidak memiliki akses terhadap sumur dengan air siap konsumsi karena kedalaman sumur yang mereka miliki kurang. Oleh sebab itu mereka hanya memanfaatkan air untuk

\footnotetext{
${ }^{12}$ Disarikan dari wawancara dan observasi
} 
keperluan cuci dan kakus saja. Sedangkan untuk pemenuhan kebutuhan air bersih siap minum, bagi rumah tangga yang tidak memiliki sumur yang layak minum, mereka akan memintanya kepada tetangga yang memilikinya. Sebagian lainnya mengambil ke sumur umum. Ada pula yang melakukan kegiatan mencuci di sungai, jarak tempuh dari perkampungan sekitar $500 \mathrm{~m}$. Air yang mereka sudah ambil dari sumur masih dikumpulkan di dalam jerigen-jerigen sebagai pasokan air mereka untuk kebutuhan sehari-hari, namun bagi rumah tangga yang memiliki akses terhadap air yang cukup, mereka menampungnya di dalam torn yang lebih besar.

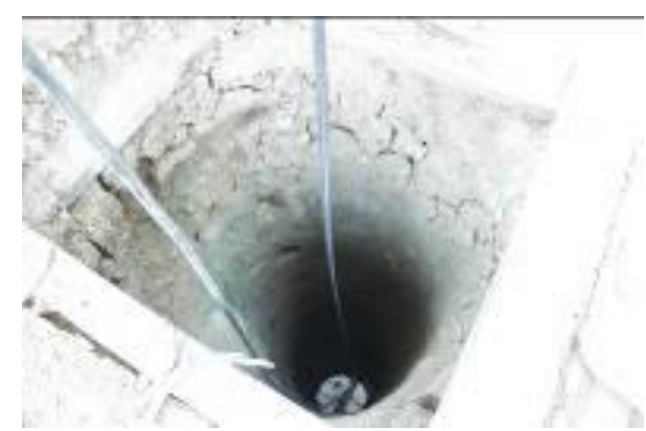

Gambar 3. Sumur Gali Umum Sumber : Dok. Pribadi, 2017.

Sanitasi berupa jamban dan pembuangan limbah rumah tangga belum tertata dengan baik. Hampir semua rumah memang telah difasilitasi jamban yang dilengkapi dengan WC di dalam rumah. Begitu pula septic tank rata-rata setiap rumah membuatnya dan ditempatkannya di luar rumah, baik itu di depan, belakang, ataupun pinggir rumahnya masing-masing. Hanya saja pembuangan limbah rumah tangga yang berasal dari jamban tidak disalurkan ke saluran pembuangan limbah yang layak. Hampir tidak ada sistem saluran pembuangan limbah rumah tangga yang ditemukan di Dusun Cipondoh. Mereka membuang limbah begitu saja keluar rumah hingga menciptakan genangan-genangan air di sekitar rumahnya. Begitu pula halnya dengan sampah, hampir tidak ada tempat penampungan sampah sementara di Dusun Cipondoh, untuk membuang sampah. Biasanya mereka membakarnya atau membuangnya begitu saja di lahan kosong yang ada.

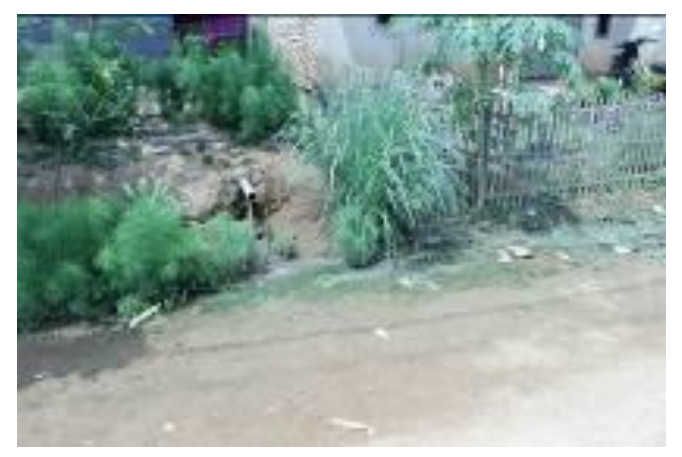

Gambar 4. Genangan Air hasil Pembuangan Limbah Rumah Tangga Sumber: Dok. Pribadi, 2017.

Sarana dan prasarana di Dusun Cipondoh juga masih sangat minim. Pembangunan infrastruktur berupa jalan desa belum rampung. Sejak masyarakat menempati kawasan tersebut pada tahun 2015, hingga saat ini perhatian pemerintah belum ada, khususnya untuk memperbaiki jalan desa yang masih berupa tanah. Oleh sebab itu akses jalan untuk mencapai Dusun Cipondoh masih sulit, jalan tanah yang licin ketika hujan cukup sulit untuk dilalui kendaraan. Pengerasan jalan menggunakan batu diinisiasi warga barubaru ini. Musyawarah warga merekomendasikan masing-masing kepala keluarga untuk berkontribusi dalam pembuatan jalan dengan menyumbang 2,5 m3 batu kali.

Kondisi infrastruktur yang masih belum memadai membuat akses transportasi umum menuju Dusun Cipondoh juga belum ada. Mereka masih mengandalkan transportasi pribadi berupa mobil atau motor, bahkan berjalan kaki. Anak-anak Dusun Cipondoh yang masih bersekolah, bagi siswa SD mereka masih bisa bejalan kaki karena sarana pendidikan SD masih relatif dekat ditempuh. Namun bagi siswa setara SMP/SLTA mereka harus ke pusat kecamatan untuk bisa bersekolah, sehingga motor digunakan 
sebagai sarana transportasi yang relatif lebih cepat untuk menempuh jarak jauh.

Terdapat sebuah masjid di Dusun Cipondoh, namun sarana rekreasi dan olah raga, seperti taman atau lapangan olah raga belum tersedia. Fasilitas kesehatan umum seperti Puskemas juga belum ada, apabila ada warga yang membutuhkan pengobatan, mereka harus pergi ke layanan kesehatan terdekat yang berada di Kecamatan Wado. Jarak tempuh menuju tempat itu ditempuh sekitar kurang lebih satu jam. Kondisi ini mengakibatkan masyarakat Dusun Cipondoh kurang mendapatkan akses pelayanan kesehatan yang cepat dan memadai agar bisa beradaptasi di dalam kondisi lingkungan alam yang masih terbilang cukup ekstrim.

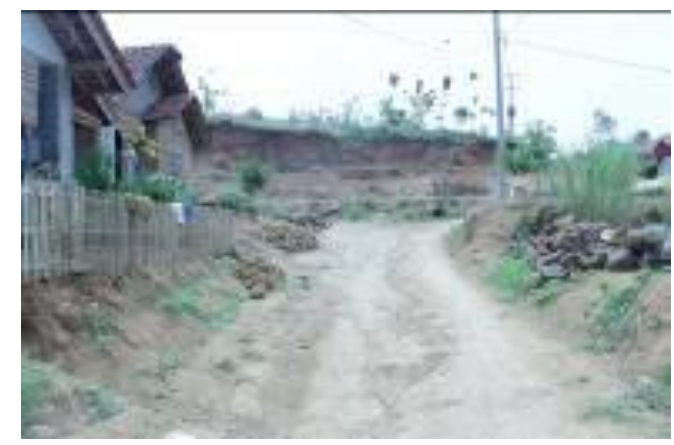

Gambar 5. Infrastruktur Jalan Dusun Cipondoh Sumber: Dok. Pribadi, 2017.

Utilitas umum seperti listrik, telepon, dan bahan bakar sudah ada hanya dalam kondisi yang terbatas. Jaringan listrik sudah terpasang. Aturan pemasangan jaringan listrik di Dusun Cipondoh, jika warga mempunyai Kartu Indonesia Sejahtera (KIS) maka dapat dipasang listrik sebesar 450 atau 900 Watt di rumahnya. Sedangkan warga yang tidak mempunyai KIS hanya boleh memasang listrik sebesar 1300 watt. Biaya listrik yang harus mereka keluarkan bagi rumah tangga dengan daya 1300 watt adalah 50 ribu untuk 2 minggu hingga 300 ribu, tergantung pemakaian. Jaringan komunikasi telepon sudah masuk, dengan dibangunnya beberapa tower telekomunikasi swasta di sekitar pemukiman, seperti Telkomsel dan XL. Bahan bakar yang biasa digunakan oleh warga Cipondoh berupa gas elpiji tabung 3 $\mathrm{kg}$, namun masih ada keluarga yang menggunakan kayu bakar untuk keperluan dapur. Kayu-kayu bakar itu mereka peroleh di lahan-lahan kosong sekitar kampung.

Geliat perekonomian dan mata pencaharian warga Dusun Cipondoh masih sangat relatif. Setelah resettlement dilakukan pada tahun 2015, masih banyak warga tanpa memiliki mata pencaharian tetap. Usaha-usaha produktif yang biasa mereka lakukan sebagai petani di Desa Padajaya sebelumnya tidak dapat lagi dikerjakan di tempat baru mereka, karena tidak adanya lahan garapan. Dengan luas tanah $110 \mathrm{~m} 2$, sangat sulit bagi mereka untuk bercocok tanam, sehingga mereka membutuhkan usaha-usaha produktif lain untuk bertahan hidup. Seperti misalnya menggarap lahan kosong di bukit sebelah, menangkap ikan di waduk, atau wiraswasta berupa warung, atau toko-toko kecil lainnya. Keterbatasan lahan pekerjaan dan tingkat pendidikan, mengharuskan mereka untuk mencari alternatif pekerjaan lain. Buruh merupakan pekerjaan yang paling banyak dilakukan oleh warga Dusun Cipondoh, sehingga sebagian besar tenaga produktif di Dusun Cipondoh bekerja menjadi buruh kayu, atau bangunan ke kota kabupaten, sehingga hanya kaum tua, ibu-ibu rumah tangga dan anak-anaklah yang tinggal. Ibu-ibu yang masih berusia produktif beberapa di antaranya berdagang bakulan keliling untuk menambah penghasilan.

Keberadaan Waduk Jatigede belum mampu memberikan dampak yang signifikan terhadap peningkatan kesejahteraan masyarakat, khususnya mereka yang terkena dampak relokasi dan resettlement. Kebijakan pemerintah setempat untuk melarang keberadaan 
kolam ikan terapung ${ }^{13}$, membuat pilihan mata pencaharian semakin terbatas.

Pemberdayaan perekonomian khususnya pertanian pernah dilakukan oleh Dinas Ketahanan Pangan dan Peternakan Jawa Barat yang bekerja sama dengan ALG (Academic Leadership Grant) Unpad pada tahun 21017 ini, memberikan pelatihan terkait pemanfaatan lahan kosong yang ada di sekitar rumah. Seperti, halaman atau pekarangan, untuk dimanfaatkan menjadi kebun tanaman pangan sebagai bahan konsumsi seharihari.

"Eta kanggo pemerdayaan lingkungan, misalkeun ayeuna gaduh pekarangan rumah, dipelakan naon kitu. Eta nembe ka dinya wungkul teu ngaieukeun pemberdayaan. Dina gaduh pakarangan sakieu $k u$ poly bag dipelakan naon, kanggo kabutuhan sehari-hari." ${ }^{14}$

Bantuan dari beberapa lembaga nirlaba juga pernah diperoleh warga Dusun Cipondoh sebagai upaya pemberdayaan masyarakat dengan menggulirkan peternakan domba. Bantuan domba pertama kali diberikan sebanyak 5 ekor betina dan 1 jantan untuk $10 \mathrm{KK}$. Domba-domba tersebut kemudian digulirkan kepada KK yang lain apabila telah menghasilkan keturunan.

"Ayeuna misalkeun dipasihan
saurang teh 5 betina sareng 1

13 Di Waduk Saguling dan Cirata, warga terdampak dibolehkan membuat keramba terapung sebagai alternatif mata pencaharian pasca penggenangan, tidak demikian dengan Waduk Jatigede. Hal ini disebabkan menurut pendapat pemerintah setempat seringkali terjadi over capacity atau terlalu banyaknya keramba dari yang seharusnya dibolehkan untuk dibangun diatas waduk, sehingga kualitas air menjadi jenuh yang berakibat pada kualitas dan kuantitas ikan yang dihasilkan kurang baik.

\footnotetext{
${ }^{14}$ Wawancara dengan Bapak Teten, 17 Oktober 2017.
}

jantan tah tos upami tos anakan engke dialihkeun deui ka nu sanes. "15

Adanya peternakan domba sedikit banyak telah membantu perekonomian masyarakat setempat. Domba-domba yang telah cukup umur dapat dijual, sedangkan kotorannya dimanfaatkan sebagai pupuk kompos. Pembuatan kompos dilakukan dengan cara menimbun kotoran ternak dengan plastik terpal atau menguburnya dalam lubang buatan. Penimbunan dilakukan untuk menimbulkan efek panas, sehingga kotoran lebih cepat terurai. Pemanfaatan pupuk in masih sebatas untuk konsumsi pribadi warga, yang biasa digunakan sebagai pupuk organik untuk berbagai tanaman pangan yang mereka tanam halaman rumahnya.

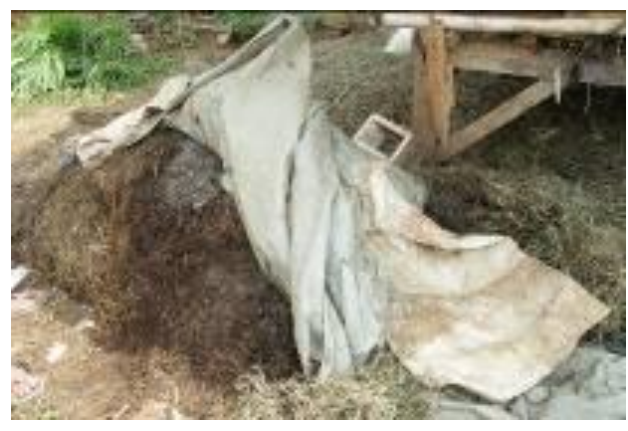

Gambar 6. Pembuatan Kompos dari Kotoran Domba

Sumber: Dok. Pribadi, 2017.

Adanya perubahan pada kondisi kesehatan merupakan ekses nyata yang dirasakan warga Dusun Cipondoh. Kondisi lingkungan alam yang cukup ekstrim dari cuaca yang cukup panas pada saat siang hari dan dingin menggigit ketika malam tiba, memungkinkan terjadinya berbagai macam penyakit baru yang sebelumnya jarang mereka rasakan di tempat tinggal sebelumnya. Penyakit seperti batuk, flu, dan demam lebih sering menyerang. Anakanak berpotensi lebih rentan terkena dampaknya, penyakit batuk flu dan demam

\footnotetext{
${ }^{15}$ Wawancara dengan Bapak Teten, 17 Oktober 2017.
} 
ini lebih sering menghinggapi mereka terutama apabila cuaca sangat panas, penyakit dapat menyerang kurang lebih tiga kali dalam setahun. Bagi manula penyakit linu atau ngilu pada tulang dan persendian lebih sering terasa. Belum lagi gangguan binatang seperti nyamuk merupakan hal yang paling lumrah di kondisi cuaca panas. Peningkatan suhu dimungkinkan karena masih kurangnya penghijauan sebagai efek dari cut $_{\text {and }}$ fill $^{16}$ lahan manjadi perumahan.

Dalam rangka menyikapi kondisi lingkungan yang ekstrim tersebut masyarakat Dusun Cipondoh mengembangkan penghijauan lahan. Usaha-usaha penghijauan telah dimulai sejak 2015 melalui penanaman tanaman keras jenis sengon yang diperoleh dari bantuan sosial dari sebuah lembaga nirlaba. Bibit-bibit pohon tersebut ditanam warga di lahan-lahan kosong sekitar kampung. Selain itu baru-baru ini pemerintah daerah setempat juga memberikan bantuan penghijauan berupa pohon mangga gedong yang dibagikan merata kepada seluruh kepala keluarga untuk ditanam di pekarangan rumah warga.

Perataan tanah bukit yang saat ini telah berubah menjadi pemukiman melalui mekanisme cut and fill lahan, ternyata tidak seluruhnya sempurna. Di beberapa titik pemukiman tanah masih relatif labil. Ini dibuktikan dengan adanya beberapa rumah yang tanahnya amblas, sehingga bangunan di atasnya pun ikut amblas. Terutama, mereka yang menempati lahan di bibir lembah. Rumah-rumah yang baru saja dibangun dari uang kerohiman, sebagian harus rubuh dan rata dengan tanah, hingga kerusakannya cukup parah dan tidak dapat ditempati lagi. Para

16 Cut and fill merupakan sebuah proses pengerjaan tanah yang terdiri dari dua kata yaitu cut (penggalian) dan fill (penimbunan). Artinya pengerjaan tanah ini dilakukan dengan mengambil atau menggali sejumlah massa tanah disuatu wilayah untuk kemudian dipindahkan atau ditimbun di tempat lain. penghuninya terpaksa pindah ke tempat lain yang lebih aman.

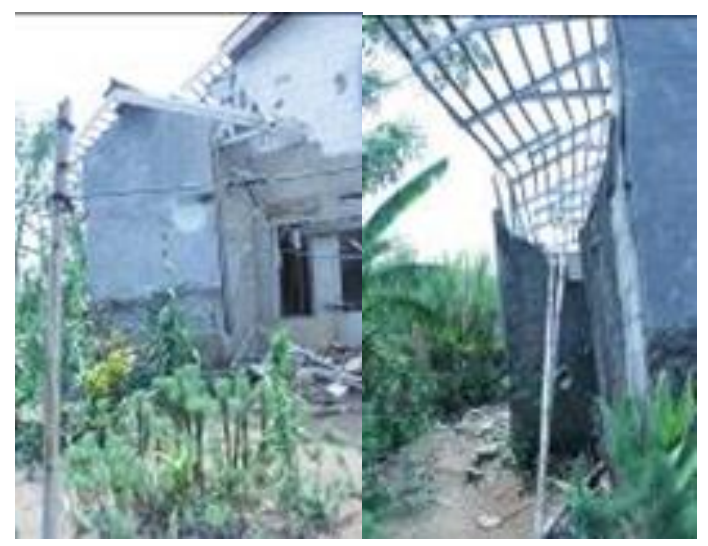

Gambar 7. Rumah Amblas di Dusun Cipondoh

Sumber : Dok. Pribadi, 2017.

\section{Upaya Adaptif Masyarakat Cipondoh di Lingkungan Baru}

Sarana sanitasi dalam sebuah pemukiman memegang peranan yang sangat penting, khususnya untuk mengontrol kondisi kesehatan masyarakat yang menempati pemukiman tersebut. Sebuah pemukiman yang baik dan sehat sebagaimana di ungkapkan Krieger dan Higgins (2002) dalam Keman (2005: 30) harus mengutamakan keberadaan sarana sanitasi seperti penyediaan air bersih, pembuangan sampah, dan tentunya utilitas sanitasi itu sendiri seperti MCK, dan pembuangan limbah rumah tangga. Apa yang ada di Dusun Cipondoh pada dasarnya telah memenuhi unsur-unsur sebuah pemukiman seperti terdapatnya MCK di semua rumah tangga yang ada, serta sarana pembuangan limbah dan kotoran seperti septic tank, hanya justru sarana-sarana yang lain belum sepenuhnya mendukung.

Supaya dapat dikategorikan sebagai pemukiman sehat, sepertinya air bersih masih memegang peranan yang sangat penting. Keberadaan air bersih yang mudah diakses untuk kepentingan seharihari khususnya konsumsi rumah tangga masih sulit diakses oleh beberapa rumah tangga yang tidak memiliki sumur. Kualitas air yang kurang baik apabila 
dikonsumsi dapat saja berakibat pada terjadinya penurunan tingkat kesehatan. Hal yang sama dapat terjadi juga pada saluran pembuangan air kotor dan limbah, yang menurut hasil pengamatan masih belum memadai. Limbah dan kotoran rumah tangga yang dibuang begitu saja di sekitar pemukiman tanpa adanya saluran pembuangan yang representatif dapat pula menimbulkan dampak kesehatan yang cukup serius.

Hal ini sebenarnya dapat difahami mengingat pemukiman Dusun Cipondoh dibangun hanya berdasarkan site plane melalui cut and fill lahan supaya dapat dibangun pemukiman secara mandiri oleh masyarakat, tanpa ada perencanaan pembuatan dan pembangunan infrastruktur lebih lanjut. Tidak adanya pengelola pemukiman yang profesional sebagaimana diungkapkan oleh Keman (2005: 32), mengakibatkan kenyamanan sebuah lingkungan pemukiman menjadi hal yang sulit untuk dicapai. Kenyamanan yang didasarkan pada kelengkapan sarana dan prasarana dasar, serta pembangunan infrastruktur masih jauh dari harapan seluruh warga Dusun Cipondoh. Saat ini mereka hanya berharap pada bantuanbantuan pemerintah dan lembaga-lembaga swasta untuk mengatasi kesulitan mereka terhadap akses-askes infrastruktur, ekonomi, kesehatan, pendidikan, lingkungan, dan sanitasi.

Harapan-harapan yang digantungkan pada asa dan kemurahan hati pemerintah daerah setempat untuk setidaknya meringankan beban hidup warga Dusun Cipondoh, ternyata tidak juga kunjung datang. Di sisi lain kehidupan harus terus berjalan, dan mereka harus tetap dapat bertahan dengan segala keterbatasan. Upaya-upaya adaptasi pun dilakukan untuk menjamin keberlangsungan hidupnya. Adaptasi ekonomi memang memegang peranan penting dalam menjaga keberlangsungan hidup warga, dengan adanya penghasilan mereka bisa makan untuk bertahan hidup. Namun demikian tidak berarti adaptasi lingkungan dan sanitasi kurang berperan, sebaliknya kedua hal ini sangat penting, karena efeknya terhadap kondisi kesehatan warga di Dusun Cipondoh.

Adaptasi atau bentuk-bentuk penyesuaian ini telah dilakukan selama dua tahun, tantangan-tantangan yang dihadapi dengan segala keterbatasan telah mampu mereka lalui dengan pola-pola tindakan yang dilakukan secara berulang-ulang. Perilaku masyarakat terhadap lingkungan dan sanitasinya, seperti pemenuhan kebutuhan air untuk makan dan minum. Strategi mereka tidak terfokus pada sumber air bersih yang berasal dari sumursumur warga saja, tetapi mengembangkan alternatif pilihan lain seperti pembangunan sumur umum, atau sungai sebagai sarana MCK, pembuangan limbah rumah tangga juga merupakan perilaku adaptif mereka terhadap kondisi ketidakberdayaan ekonomi, begitu pula halnya dengan pembuangan sampah. Sampah rumah tangga merupakan sampah domestik paling banyak yang diproduksi oleh setiap rumah tangga, untuk meminalisirnya mereka membakar sampah-sampah tersebut atau membuangnya di lahan-lahan kosong. Hal ini dilakukan semata karena di lingkungan pemukiman dengan akses yang sangat terbatas itu, pelayanan kebersihan tidak dapat diharapkan, sehingga mereka mengembangkan sendiri pola-pola penanggulangannya.

Begitu pula halnya dalam menanggulangi kondisi lingkungan alam, warga Dusun Cipondoh mengembangkan penghijauan sebagai bagian dari strategi adaptasi mereka terhadap kondisi cuaca yang ekstrim. Dengan dilakukannya penanaman pohon, warga berharap lingkungan alam mereka menjadi lebih sejuk dan lebih hijau. Eksesnya penyakitpenyakit yang timbul dari kondisi cuaca panas dapat diminimalkan. Pada kondisi yang lain tanaman mangga yang ditanam di pekarangan-pekarangan rumah warga suatu saat akan berbuah, dan buahnya dapat dijual untuk pemenuhan kebutuhan sehari-hari. Konsep yang sama mereka 
terapkan juga dalam membuat infrastruktur jalan. Sistem gotong royong yang mereka lakukan untuk membuat pengerasan jalan menggunakan batu kali secara swadaya merupakan upaya adaptif warga Dusun Cipondoh untuk memperoleh akses jalan perkampungn yang lebih layak daripada jalan tanah.

\section{PENUTUP}

Tindakan maupun strategi yang dilakukan warga Dusun Cipondoh untuk menyesuaikan diri dengan lingkungannya tidak terjadi begitu saja, melainkan telah terpola karena tersusun dari sejumlah tindakan-tindakan yang sama yang dilakukan berulang-ulang. Pola-pola tindakan ini muncul karena sebelumnya ada pengetahuan. Pengetahuan tentang kondisi lingkungan alam, sanitasi, kesehatan, maupun sarana dan prasarana dasar penunjang kehidupan suatu masyarakat diperoleh dengan cara melihat, mendengar, dan merasakan sendiri pengalaman-pengalaman lainnya, ketika mereka mulai hidup dan menetap di Dusun Cipondoh. Mereka melihat ada hal-hal yang kurang, mereka mendengar keluhankeluhan, dan mereka juga merasakan adanya ketidaknyamanan. Konsep tahu ini kemudian diwujudkan dalam sikap sebagai reaksi atau respon terhadap segala keterbatasan yang mereka alami. Pengetahuannya mengenai kondisi lingkungan dan segala keterbatasannya, membuat mereka menyusun strategistrategi untuk bertindak. Tahapan penyusunan strategi tindakan inilah yang dimaknai dengan sikap. Pada tahap berikutnya pengetahuan dan sikap ini dimekanisasi dalam bentuk tindakan, untuk mewujudkan strategi adaptasi mereka terhadap lingkungan alam, dan sosialnya.

Berdasarkan pemaparan hasil penelitian di atas perlu kiranya dibuat beberapa rekomendasi mengenai hal-hal yang harus dilakukan terkait dengan keberadaan dan kondisi masyarakat terdampak pembangunan Waduk Jatigede. Walau bagaimanapun masyarakat Dusun
Cipondoh pada dasarnya memiliki hak yang sama dengan warga lainnya sebagai sesama warga negara di republik ini, dalam mengakses kehidupan yang layak sebagaimana diamanatkan dalam UUD 1945 pasal 27 dan pasal 34 yaitu dengan :

1. Mengoptimalkan sumber daya manusia yang ada dengan membuka lahan-lahan pekerjaan yang layak sebagai upaya pemenuhan kebutuhan dasar mereka;

2. Mengupayakan pemenuhan sarana dan prasana lingkungan dan sanitasi yang baik untuk mendukung kesejahteraan fisik dan mental warga terdampak;

3. Memenuhi kebutuhan infrastruktur jalan yang sangat penting bagi aksesibilitas dan mobilitas warga terdampak.

\section{DAFTAR SUMBER}

1. Jurnal, Makalah, Laporan

\section{Penelitian, Skripsi, dan Tesis}

Amaliah, Siti. "Hubungan Sanitasi Lingkungan dan Faktor Budaya Dengan Kejadian Diare Pada Anak Balita di Desa Toriyo, Kecamatan Bendosari, Kabupaten Sukoharjo" Makalah dalam Prosiding Seminar Nasional Universitas Muhammadiyah, Semarang, 2010.

Bartolome, Leopoldo Jose., Chris de Wet, Harsh Mander, Bijay Kumar Nagraj. $2000 . \quad$ "Displacement, Resettlement,Rehabilitation, Reparation, and Development". Makalah dalam WCD Thematic Review Social Issues I.3. Cape Town : World Commission on Dams (WCD).

Kasnodiharjo dan Musadad, Anwar "Perilaku Hidup Bersih dan Sehat yang Terkait dengan Hygien Perorangan, Gaya Hidup dan Kondisi Sanitasi Lingkungan di Kepulauan Seribu, DKI Jakarta" dalam Jurnal Ekologi Kesehatan Vol. 8 No.1. Maret 2009. Hlm. 886-894.

Kasnodihardjo dan Elsi, Elsa. "Deskripsi Sanitasi Lingkungan, Perilaku Ibu, dan Kesehatan Anak" dalam Jurnal Kesehatan Masyarakat Nasional Vol. 7 No. 9. April 2013. Hlm. 415-420. 
Keman, Soedjadji. "Kesehatan Perumahan dan Lingkungan Pemukiman" dalam Jurnal Kesehatan Lingkungan Vol. 2 No.1. Juli 2005. Hlm. 29-42.

Mulyani, Tri. 2016

\begin{tabular}{|c|c|}
\hline Kebijakan & Pemerintah \\
\hline Masyarakat & Terkena Dampak \\
\hline bangunan & Jatigede \\
\hline $\begin{array}{l}\text { Kabupaten } \\
\text { Yogvakarta }\end{array}$ & $\begin{array}{l}\text { Sumedang. } \\
\text { IS UNY. }\end{array}$ \\
\hline
\end{tabular}

Nureni, Lela. 2011.

Dampak Pembangunan Bendungan Jatigede terhadap Reorientasi Mata Pencaharian Masyarakat di Daerah Calon Genangan Bendungan Jatigede Kabupaten Sumedang. Skripsi. Bandung : FPIPS UPI.

Nurlela, Ela. 2012.

Dampak Pembangunan Waduk Jatigede Terhadap Masyarakat Calon Genangan (Studi Sosiologi Pembangunan Desa Leuwihideung, Sumedang). Bandung. Sripsi. FPIPS UIN Sunan Gunung Jati.

Puspitawati, Natalia. "Sanitasi Lingkungan yang Biak Mempengaruhi Status Gizi Buruk pada Balita" dalam Jurnal Stikes. Vol.6 No.1 Juli 2013.Hlm. 74-83.

Sajiada, Agsa., Santi, Devi Nuraini Santi., dan Naria, Evi. "Hubungan Personal Hygien dan Sanitasi Lingkungan dengan Keluhan Penyakit Kulit di Kelurahan Denai, Kecamatan Medan Denai, Kota Medan Tahun 2012" dalam Jurnal Usu. Vol.2 No.2. Maret 2013. Hlm. 1-8.

Setiawan, Irvan. "Mengenang Upacara Ngalokat Walungan Cimanuk di Wilayah Genangan Waduk Jatigede Kabupaten Sumedang" dalam Patanjala. Vol.8 No.1 Maret 2016. HIm. 101-116.

Wiryawan. Bangkit A. "Social Impact of Jatigede Dam Construction". Makalah dalam IAIA Symposium, Manila, 20-22 February 2017.

Yuliati, Rafael Djajakusli, Burhanudin Bahar. "Hubungan Sanitasi Lingkungan dan Hygien Perorangan dengan Kejadian Infestasi Kecacingan pada Murid SD di Kelurahan Pannampu, Kota Makasar" dalam Jurnal Media Kesehatan
Masyarakat Indonesia. Vol.6 No.1 Januari 2010 Hal. 22-27.

\section{Buku}

Bennett, John W. 1976.

The Ecological Transition : Cultural Anthropology And Human Action. New York : Pergamaon Press Inc.

Notoatmodjo, Soekidjo. 2003.

Ilmu kesehatan masyarakat (prinsipprinsip dasar). Jakarta: PT Rineka Cipta.

Saharuddin. 2007. Antropologi Ekologi dalam Adiwibowo, Soeryo (Ed). Ekologi Manusia. Bogor : Fakultas Ekologi Manusia IPB.

Semiawan, Conny R. 2010

Metode Penelitian Kualitatif. Jakarta : Grasindo.

Surahman, dan Supardi, Sudibyo. 2016. Ilmu Kesehatan Masyarakat PKM. Jakarta : Kementerian Kesehatan Republik Indonesia.

\section{Internet}

Pitoko, Ridwan Aji. "Waduk Jatigede Beroperasi Penuh “ diakses dari http://properti.kompas.com/read/2017/0 4/07/220000521/waduk.jatigede.beroper asi.penuh. Tanggal 6 November 2017, Pukul 10.25 WIB.

"Bedol Desa" diakses dari https://www.kamusbesar.com/bedoldesa. Tanggal 7 November 2017, Pukul 09.45 WIB. 
